\begin{abstract}
The petrale sole (Eopsetta jordani) is a commercially and ecologically important flatfish found throughout the continental shelf from California through British Columbia, Canada. Although stock assessments are routinely conducted along the West Coast of the United States for this population, these assessments have depended on limited data for estimating reproductive output. In this analysis, the reproductive strategy for this species was revisited, fecundity estimates were updated, and size-dependent fecundity relationships were established from fish collected off California and the Pacific Northwest. Results of histological analysis indicate that petrale sole exhibit a determinate batch spawning strategy, with potential annual fecundity (PAF) set prior to the release of eggs over the course of several spawning events. Both PAF and relative PAF (weight-specific fecundity) increased significantly with maternal length and weight. Regional differences in the strength of the relationship between relative $\mathrm{PAF}$ and size indicate that the maternal effect is stronger in the Pacific Northwest; however, more data are necessary to confirm regional patterns. Because reproductive output was not proportionate with female size, fisheries managers should consider using relative PAF in determining the reproductive potential of this stock.
\end{abstract}

Manuscript submitted 15 November 2018. Manuscript accepted 10 September 2019. Fish. Bull. 117:291-302 (2019).

Online publication date: 30 September 2019. doi: $10.7755 /$ FB.117.4.2

The views and opinions expressed or implied in this article are those of the author (or authors) and do not necessarily reflect the position of the National Marine Fisheries Service, NOAA.

\title{
Reproductive ecology and size-dependent fecundity in the petrale sole (Eopsetta jordani) in waters of California, Oregon, and Washington
}

\author{
Lyndsey S. Lefebvre (contact author) ${ }^{1,2}$ \\ Cherisa L. Friedlander ${ }^{2}$ \\ John C. Field ${ }^{2}$ \\ Email address for contact author: lyndsey.lefebvre@noaa.gov \\ ${ }^{1}$ Institute of Marine Sciences \\ University of California Santa Cruz \\ 1156 High Street \\ Santa Cruz, California 95064 \\ Present address for contact author: Integrated Statistics Inc. \\ Population and Ecosystems Monitoring and Analysis Division \\ Northeast Fisheries Science Center \\ National Marine Fisheries Service, NOAA \\ 166 Water Street \\ Woods Hole, Massachusetts 02543 \\ ${ }^{2}$ Fisheries Ecology Division \\ Southwest Fisheries Science Center \\ National Marine Fisheries Service, NOAA \\ 110 McAllister Way \\ Santa Cruz, California 95060
}

The petrale sole (Eopsetta jordani) is a commercially important flatfish in the family Pleuronectidae (righteyed flounders). Although their range extends from Baja California, Mexico, to the western Gulf of Alaska, their greatest abundance and commercial significance is generally from Santa Barbara, California, through British Columbia, Canada (Alverson and Chatwin, 1957; CDFW, 2013). Female petrale sole grow considerably larger than males and can reach a maximum total length (TL) of $70 \mathrm{~cm}$ (although fish larger than $60 \mathrm{~cm}$ are rarely encountered) and live up to 31 years (Haltuch et al., 2013; Stawitz et al., 2016). Hannah et al. (2002) estimated the length at $50 \%$ maturity at $33 \mathrm{~cm}$ (corresponding to an age of 5 years) for fish collected off Oregon. Petrale sole migrate seasonally between shallow feeding grounds (with depths of 70-200 m), where they disperse across the continental shelf from March through October, and deeper spawning grounds (with depths of 290-440 m), where they form discrete aggregations along the outer shelf during late fall and winter (November-February) (Ketchen and Forrester, 1966; CDFW, 2013; Stawitz et al., 2016). Tagging data indicate that individuals are capable of dispersing several hundred miles, although most individuals have high fidelity to winter spawning habitats (Ketchen and Forrester, 1966; Pedersen, 1975).

The petrale sole fishery off the U.S. Pacific coast has a long history, having started in the late 1800s off California and Oregon (CDFW, 2013). The first stock assessments in U.S. waters evaluated only populations north of Cape Blanco, Oregon, because of data constraints (Turnock et al., 1993; Sampson and Lee, 1999), but recent stock assessments have assumed a single coast-wide stock (Haltuch and Hicks, 2009; Haltuch et al., 2013). The petrale 
sole is currently treated as a single stock in waters of Canada for management purposes (Starr and Fargo, 2004), although it is believed that there are 2 distinct stocks in British Columbia (Ketchen and Forrester, 1966; Starr and Fargo, 2004). Stock depletion was evident as early as the 1950s and 1960s in waters of both the United States (Haltuch et al., 2013) and Canada (Ketchen and Forrester, 1966), following increasing landings and targeting of petrale sole on their winter spawning grounds. Recent stock assessments indicate that the population in the United States was below target levels (25\% of the unfished spawning output) from 1962 through 2014 and below the overfished level (12.5\% of the estimated unfished spawning output) from 1979 through 2011 (Haltuch et al., 2013; Stawitz et al., 2016), although the stock was not declared overfished until 2009. Following subsequent reductions in allowable catch, and due in part to strong recruitment events, the stock abundance increased sharply from 2009 through 2015, and the stock was declared rebuilt in 2014 (Stawitz et al., 2016).

High priority research recommendations in recent petrale sole stock assessments engendered new studies on the reproductive biology of the stock and on spatial variability in growth and recruitment (Haltuch et al., 2011, 2013; Stawitz et al., 2016). The only published estimates of fecundity for petrale sole come from collections in the 1950s off California (Porter, 1964), and the reproductive strategy of this species was established solely on the basis of visual (macroscopic) evaluation of the ovaries. Annual fecundity estimates in that study ranged from 150,000 to 1.49 million eggs, and females were presumed to exhibit a determinate total spawning strategy (Murua and Saborido-Rey, 2003), releasing all eggs in a single spawning event annually. Relationships between maternal size and relative fecundity (the number of eggs per gram of maternal somatic weight) were not examined. Subsequently, stock assessments for this species have assumed that fecundity is proportional to maternal length.

In response to research recommendations in recent stock assessments and in cooperation with The Nature Conservancy and commercial fishermen, mature female petrale sole were collected from spawning grounds off Central California (Morro Bay) in the 2014-2015, 20152016, and 2016-2017 reproductive seasons (AugustFebruary) to estimate annual fecundity. Collections were expanded in the 2015-2016 and 2016-2017 reproductive seasons to include samples caught off Oregon and Washington with cooperation from the West Coast Groundfish Bottom Trawl Survey of the Northwest Fisheries Science Center (NWFSC), National Marine Fisheries Service (NMFS) (Keller et al., 2012), and from Washington Department of Fish and Wildlife (WDFW) commercial port samplers. Histological analysis of ovarian tissue was used to determine the reproductive strategy of petrale sole and to identify suitable samples for inclusion in fecundity analyses. The relationships between fecundity and maternal size were established or updated, and regional differences between fish collected off California and those from waters of the Pacific Northwest (Oregon and Washington) were examined. The majority of samples collected for this study came from commercial fishermen who targeted fish on their spawning grounds. Because maturity estimates from fish collected on spawning grounds can be biased (Murua and Saborido-Rey, 2003), we did not attempt to update maturity ogives in this study.

\section{Materials and methods}

\section{Sample collection}

A total of 401 female petrale sole were collected from commercial and survey bottom-trawl operations off California (number of samples $[n]=291$ ), Oregon $(n=1)$, and Washington $(n=109)$ between August and February of the 2014-2015, 2015-2016, and 2016-2017 reproductive seasons (Table 1, Fig. 1). The majority $(n=250)$ were collected off Morro Bay by commercial fishermen in all 3 sampling years. Sixty females were collected by WDFW port samplers in Puget Sound, Washington, from commercial and tribal bottom trawlers, 40 in August 2015, 10 in December 2016, and 10 in January 2017. The remaining fish $(n=91)$ were collected by the NWFSC West Coast Groundfish Bottom Trawl Survey off the coasts of Washington and Oregon and off part of California (from Bodega Bay south to Point Conception) from August through October in the 2015-2016 and 2016-2017 reproductive seasons.

Fish collected by commercial fishermen in Morro Bay were stored on ice and landed 1-5 days after capture. On average, 40 fish per landing were selected to represent the entirety of the size range of the catch. Fish were transported to the Fisheries Ecology Division of the Southwest Fisheries Science Center (SWFSC) and processed within $24 \mathrm{~h}$ of landing. Total weight (TW, in grams) and TL (in millimeters) were recorded, and sagittal otoliths were removed for age analysis. Ovaries were excised, weighed (in grams), and assigned a macroscopic development stage (Table 2). Initially, the blind- and eyed-side ovarian lobes were weighed and recorded separately. A paired $t$-test conducted on 136 stage-2 and -3 ovaries demonstrated that weights did not significantly vary between blind- and eyed-side ovarian lobes $(P=0.35, \mathrm{df}=145)$.

Fish collected by WDFW were processed at an unknown time after capture, and those collected by the NWFSC were processed immediately after capture. For both collections, sagittal otoliths were removed; TL (in centimeters) and TW (in grams) were recorded; and one or both ovarian lobes (depending on their size and ability to fit in storage containers) were excised, placed individually into muslin bags, and fixed in $10 \%$ neutral buffered formalin. Ovaries were processed at the SWFSC within 1-6 months from the date of collection. Ovaries were removed from the formalin, assigned a macroscopic stage, blotted dry, and weighed (in grams). When only one ovarian lobe was present, the weight was doubled to estimate total gonad weight; a macroscopic stage-based correction 


\begin{tabular}{|c|c|c|c|c|c|}
\hline \multicolumn{6}{|c|}{ Table 1} \\
\hline \multicolumn{6}{|c|}{$\begin{array}{l}\text { Summary information for catches of petrale sole (Eopsetta jordani) during } 2014-2017 \text { off } \\
\text { California and the Pacific Northwest (Oregon and Washington), including number of sam- } \\
\text { ples by month, mean size in total length (TL), and mean age in years. An asterisk (*) indi- } \\
\text { cates a sample included in fecundity analyses. Standard deviations (SDs) of means are } \\
\text { given in parentheses. Blank cells indicate that no samples were available. }\end{array}$} \\
\hline \multirow[b]{3}{*}{ Month } & \multicolumn{5}{|c|}{ No. of samples } \\
\hline & \multicolumn{3}{|c|}{ California } & \multicolumn{2}{|c|}{ Pacific Northwest } \\
\hline & 2014-15 & $2015-16$ & $2016-17$ & $2015-16$ & $2016-17$ \\
\hline August & & $10(7)^{*}$ & & 9 & $25(3)^{*}$ \\
\hline September & & $81(27)^{*}$ & $8(1)^{*}$ & $42(11)^{*}$ & 14 \\
\hline October & & $40(7)^{*}$ & $40(6)^{*}$ & & \\
\hline December & 12 & $39(1)^{*}$ & & & $10(7)^{*}$ \\
\hline January & 20 & 1 & & & $10(1)^{*}$ \\
\hline February & 40 & & & & \\
\hline Total & 72 & 171 & 48 & 51 & 59 \\
\hline Size range (mm TL) & $336-555$ & $330-600$ & $305-545$ & $300-520$ & $280-450$ \\
\hline Mean size (SD) & $441(39)$ & $487(47)$ & $463(40)$ & $429(55)$ & $442(69)$ \\
\hline Age range (years) & $4-14$ & $5-20$ & 4-14 & $3-10$ & $4-15$ \\
\hline Mean age (SD) & $7.7(2.0)$ & $10.6(3.5)$ & $8.0(2.0)$ & $6.6(1.9)$ & $10.0(3.1)$ \\
\hline No. of samples aged & 72 & 147 & 30 & 40 & 20 \\
\hline
\end{tabular}

factor was applied to account for differences in fresh and preserved gonad weights (stage $2: F_{\text {est }}=1.02 P-3.66$; stage $3: F_{\text {est }}=0.99 P W+5.30 ; F_{\text {est }}$ is the estimated fresh weight [in grams], and $P W$ is the preserved weight [in grams]). No correction factor was necessary for ovaries of macroscopic stages 1,4 , and 5 ).

A small piece of tissue was removed from all ovaries for histological analysis. Between 2 and 6 weighed subsamples $(0.25-1.00 \mathrm{~g})$ for fecundity analyses and 1 unweighed sample for archives were collected from stage- 2 and -3 ovaries by gently teasing oocytes from fresh ovarian tissue (see the "Fecundity" section below for details). Ages were determined from otoliths through the break-and-burn technique by the aging lab at the NWFSC in Newport, Oregon. Ages were estimated from all otoliths from commercial and WDFW collections; from NWFSC collections, ages were estimated only from otoliths of fish that were used to estimate fecundity $(n=16)$.

\section{Histological analysis}

Ovarian tissue samples were fixed in $10 \%$ neutral buffered formalin for at least $48 \mathrm{~h}$ before being rinsed in water and stored in $70 \%$ ethanol. Tissues selected for histological analyses were processed according to standard histological techniques, by using paraffin as a blocking medium and staining and counterstaining sections with hematoxylin and Eosin Y (Humason, 1972). All stage-2 ( $n=142)$ and stage-3 $(n=48)$ ovaries were selected to determine their suitability for inclusion in fecundity analyses. These samples, along with haphazardly selected representatives of macroscopic stages $1(n=12), 4(n=12)$, and $5(n=16)$, were used to detail the reproductive cycle of petrale sole. Histological sections were examined at 40-250× magnification by using a compound microscope. Each ovary was assigned an ovarian phase on the basis of the stage of the leading oocyte cohort, incidence and state of atresia, and presence of postovulatory follicle (POF) complexes (Tables 2 and 3). Ovarian phases were based on descriptions of oocyte development in Wallace and Selman (1981) and Lowerre-Barbieri et al. (2011), and standard terminology suggested by Brown-Peterson et al. (2011) was used for them. To examine the size range of oocyte stages, mean maximum oocyte diameters were recorded from histological slides of 99 individuals: the diameter of the largest oocyte of the leading cohort in each of 5 fields of view was measured by using an ocular micrometer, and diameters were averaged to obtain the mean maximum oocyte diameter (Table 3). Estimates of sizes of hydrated oocytes were made from preserved whole tissue mounts from 5 stage-3 ovarian samples by using a compound microscope and ocular micrometer (Table 3).

To verify homogenous ovarian development, histology samples were collected and processed from the anterior, middle, and posterior portion of blind- and eyed-side ovarian lobes ( 6 total) from 15 females (stage- $2[n=8]$ and stage-3 $[n=7]$ ovaries). Slides were read without reference to identification number, ovarian lobe, or location. Oocyte stage of the leading cohort was recorded, and histological phase was assigned. Because there were no 


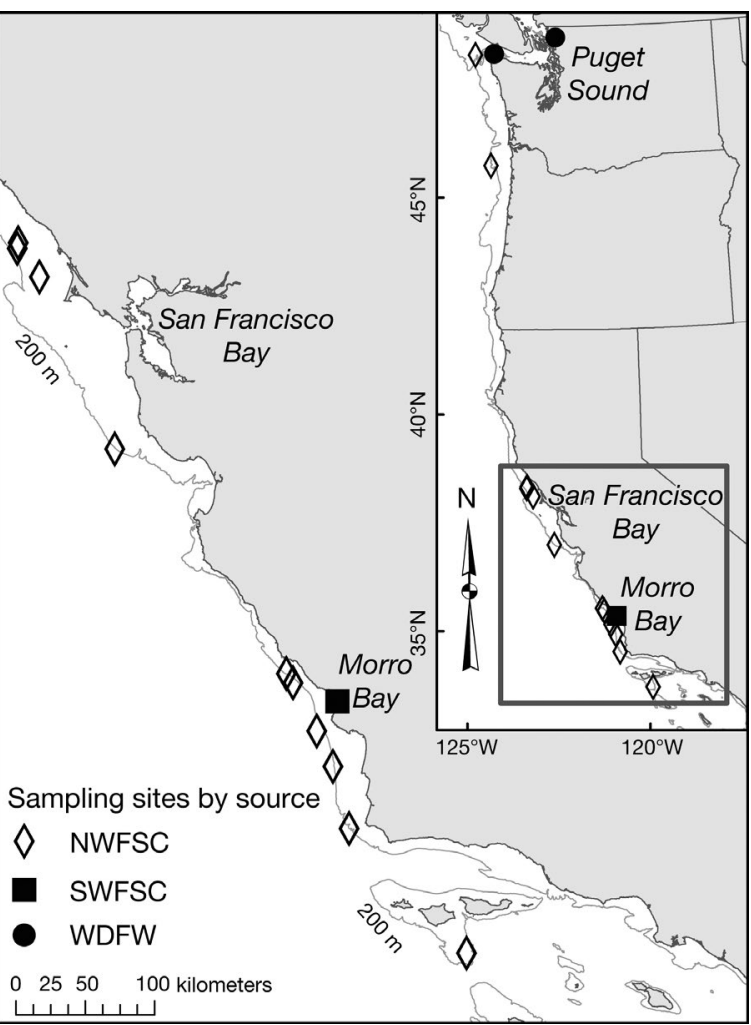

Figure 1

Map of locations where petrale sole (Eopsetta jordani) were captured during 2014-2017 off California, Oregon, and Washington. Northwest Fisheries Science Center (NWFSC) locations represent bottom-trawl survey stations; Southwest Fisheries Science Center (SWFSC) and Washington Department of Fish and Wildlife (WDFW) locations are ports of landings. Map provided by R. Miller (SWFSC).

differences among slides from the same individual, thereafter, tissue was collected from the middle portion of a randomly selected ovarian lobe.

\section{Fecundity}

Determination of fecundity strategy Fecundity strategy was determined by examination of ovarian histological sections and diagrams of oocyte size-frequency distribution for ovaries of macroscopic stages 2 and 3. Histological observations of POFs concomitant with oocytes undergoing vitellogenesis or maturation indicated that petrale sole spawned multiple times a season (batch spawning). Furthermore, the presence of a hiatus between primary and secondary growth oocytes in ovaries from fish for which spawning was imminent (with the leading oocyte cohort at late stages of vitellogenesis or further developed) and in ovaries from repeat spawners (with the leading oocyte cohort at late stages of vitellogenesis or further developed and POF present) indicated that fecundity was determinate (potential annual fecundity [PAF] set prior to the first spawning event) (Murua and Saborido-Rey, 2003).

To confirm that fecundity was determinate and to define the minimum trailing oocyte stage (least developed secondary growth oocyte present) threshold for fecundity analyses, oocyte size-frequency distributions were examined from archival samples of 20 ovaries of macroscopic stages 2 and 3 (10 of each stage). Oocytes were teased from tissue and placed into welled chambers. Photomicrographs were recorded at $70 \times$ magnification by using a digital camera (MU800 ${ }^{1}$, AmScope, Irvine, CA) mounted to a stereo microscope. Measurements of oocyte diameters were automated from photomicrographs by using the ObjectJ plugin (vers. 1.03x, University of Amsterdam, available from website) and associated modified macros (available from website) for image analysis software ImageJ (vers. 1.50i, National Institutes of Health, available from website; Schneider et al., 2012). Automated measurements recorded from damaged oocytes or detritus were manually removed. Primary growth oocytes clustered together and were difficult to tease apart. Because the maximum size for primary growth oocytes was $150 \mu \mathrm{m}$ (on the basis of measurements from 10 stage-3 ovaries; Table 2), a lower limit of $150 \mu \mathrm{m}$ was established for automated measurements. A minimum of 500 secondary growth oocytes per sample were measured. A gap between primary and secondary oocytes was observed (Fig. 2B) when the trailing oocytes had reached the secondary vitellogenic stage (Vtg2) (meaning no secondary growth oocytes were less developed than Vtg2). Recruitment from the reserve of primary growth oocytes to the spawning stock was considered complete at this time.

Fecundity processing and analyses Only macroscopic-stage-2 ovaries $(n=132)$ were considered for fecundity processing and analysis to determine PAF prior to any spawning events. Macroscopic-stage-3 ovaries were not used for fecundity analysis because of the observation of POFs (evidence of prior spawning) in all stage-3 ovaries examined histologically. Histological sections from macroscopic-stage-2 ovaries were examined for the presence of POFs $(n=0)$ and to ensure recruitment of oocytes for the reproductive season was complete. Any samples with trailing oocytes earlier than Vtg2 $(n=56)$ were excluded because of the possibility for incomplete recruitment of oocytes to the potential spawning stock. A total of 70 samples (California: $n=49$; Pacific Northwest: $n=21$ ) were included in fecundity analyses.

Homogenous oocyte density (oocytes per gram of ovarian weight) throughout the ovary was verified by comparing densities from subsamples collected from the anterior, middle, and posterior third of each ovarian lobe from 6 macroscopic-stage- 2 ovaries collected in the 20152016 reproductive season. The results of a nested analysis of variance indicate that oocyte density did not vary

\footnotetext{
${ }^{1}$ Mention of trade names or commercial companies is for identification purposes only and does not imply endorsement by the National Marine Fisheries Service, NOAA.
} 


\section{Table 2}

Macroscopic stage and histological phase descriptions of ovarian development in petrale sole (Eopsetta jordani). Oocyte stages used in this study are based on descriptions in Wallace and Selman (1981) and Lowerre-Barbierie et al. (2011), and terminology follows Brown-Peterson et al. (2011), with modifications specific to petrale sole. BV=blood vessel; $\mathrm{CT}=$ connective tissue; $\mathrm{GVB}=$ germinal vesicle breakdown; GVM=germinal vesicle migration; $\mathrm{HO}=$ hydrated oocyte; $\mathrm{LC}=$ leading oocyte cohort; $\mathrm{MB}=$ muscular bundle; $\mathrm{PG}=$ primary growth oocyte; and POF=postovulatory follicle complex; Vtg1, Vtg2, and Vtg3 represent the primary, secondary, and tertiary vitellogenic oocytes, respectively.

\begin{tabular}{|c|c|c|c|c|}
\hline $\begin{array}{l}\text { Macroscopic } \\
\text { stage }\end{array}$ & Macroscopic description & $\begin{array}{l}\text { Histological } \\
\text { phase }\end{array}$ & Subphase & Histological description \\
\hline 1 (Immature) & $\begin{array}{l}\text { Ovaries are small and elongate, } \\
\text { pale or flesh-colored with no } \\
\text { black pigmentation, and tear } \\
\text { easily. }\end{array}$ & Immature & & $\begin{array}{l}\text { Lamellae are tight and generally well } \\
\text { organized with only PG present. No } \\
\text { atresia or prominent BV, MB, or CT } \\
\text { present. Ovarian wall is thin. }\end{array}$ \\
\hline \multirow[t]{2}{*}{2 (Developing) } & $\begin{array}{l}\text { Oocytes are visible, giving } \\
\text { ovary a uniformly granular } \\
\text { appearance. Ovary is well } \\
\text { vascularized and opaque. }\end{array}$ & Developing & $\begin{array}{l}\text { Early } \\
\quad \text { developing }\end{array}$ & $\begin{array}{l}\mathrm{LC} \text { is at Vtg1 or Vtg } 2 . \text { Minor atresia may } \\
\text { be present. By the end of this stage, } \\
\text { there is a distinct hiatus between } \\
\text { primary and secondary growth oocytes. } \\
\text { Note: there appears to be no distinct } \\
\text { cortical alveolar stage oocytes in } \\
\text { petrale sole. }\end{array}$ \\
\hline & & $\begin{array}{r}\text { Spawning } \\
\text { capable }\end{array}$ & $\begin{array}{l}\text { Late } \\
\quad \text { developing }\end{array}$ & $\begin{array}{l}\text { LC is at Vtg3, GVM, or GVB stage. } \\
\text { Generally, when ovary is at this stage, } \\
\text { the earliest secondary growth oocyte } \\
\text { stage is Vtg2 or later. Minor atresia may } \\
\text { be present, and there is no evidence of } \\
\text { recent spawning (no POFs present) }\end{array}$ \\
\hline $\begin{array}{l}3 \text { (Ripe or } \\
\quad \text { running ripe) }\end{array}$ & $\begin{array}{l}\text { Large, translucent hydrated } \\
\text { eggs visible, scattered } \\
\text { throughout ovary. Hydrated } \\
\text { eggs may run under slight } \\
\text { pressure. }\end{array}$ & & $\begin{array}{l}\text { Actively } \\
\text { spawning }\end{array}$ & $\begin{array}{l}\text { LC may be Vtg3, GVM, GVB, or HO. At } \\
\text { least one stage of POF present and } \\
\text { readily distinguishable from older } \\
\text { atresia. Standing stock of secondary } \\
\text { growth oocytes at the Vtg3. Moderate } \\
\text { deltt and gamma atresia mav be present. }\end{array}$ \\
\hline 4 (Spent) & $\begin{array}{l}\text { Ovaries are flacid; brown, or } \\
\text { dark red in color and may } \\
\text { have excess ovarian fluid. } \\
\text { Residual oocytes (vitellogenic } \\
\text { or hydrated) may or may not } \\
\text { be visible. }\end{array}$ & Regressing & & $\begin{array}{l}\mathrm{PG} \text { are the most advanced nonatretic } \\
\text { oocyte present; if present, secondary } \\
\text { growth oocytes are undergoing alpha or } \\
\text { beta atresia. Lamellae appear loose and } \\
\text { disorganized. Initially, POFs are readily } \\
\text { distinguishable from other atretic } \\
\text { material. BV, MB, and CT are prominent. }\end{array}$ \\
\hline 5 (Resting) & $\begin{array}{l}\text { Ovaries are reduced in size, } \\
\text { are firmer to the touch } \\
\text { (compared to spent), are } \\
\text { pink in color, have no } \\
\text { discernable oocytes, and have } \\
\text { a gelatinous texture. }\end{array}$ & Regenerating & & $\begin{array}{l}\text { PG dominate. Some beta atretic oocytes may } \\
\text { be present but delta and gamma atresia } \\
\text { dominate. Lamellae more organized } \\
\text { compared with "regressing" ovary. BV, } \\
\text { MB, and CT are prominent. Ovarian wall } \\
\text { is thick. }\end{array}$ \\
\hline
\end{tabular}

significantly between lobes $(P=0.88)$ or location within lobes $(P=0.97)$. Subsequently, 2 fecundity subsamples were collected from the middle portion of either the blindor eyed-side ovarian lobe.

In the 2015-2016 reproductive season, weighed subsamples for fecundity analyses were $0.5-1.0 \mathrm{~g}$. Upon preliminary analysis of these samples, subsample weights were reduced to $0.25-0.50 \mathrm{~g}$ in the $2016-2017$ season. All oocytes in weighed subsamples were counted by using a stereomicroscope, and oocyte density was calculated as quotient of the oocyte count and subsample weight. Potential annual fecundity was estimated gravimetrically by multiplying the oocyte density by the ovarian weight. Relative PAF was calculated as the quotient of PAF and somatic weight (total weight minus ovarian weight). Estimates from the 2 subsamples were averaged, and the coefficient of variation was calculated. Samples were excluded from further analyses when the coefficient of variation exceeded 0.15 $(n=5)$. Fecundity estimates are potential values because any potential down-regulation through atresia was not accounted for.

Estimates of PAF and relative PAF were developed to evaluate the effects of maternal size on egg production. For most finfish, absolute fecundity increases geometrically 


\section{Table 3}

Modifications specific to petrale sole (Eopsetta jordani) for oocyte stages described by Wallace and Selman (1981) and Lowerre-Barbieri et al. (2011). Oocytes were measured from prepared histological slides, except for hydrated oocytes, which were measured from whole mount samples. $n=$ number of samples measured.

\begin{tabular}{|c|c|c|c|}
\hline Oocyte stage & Petrale sole modification & Size $(\mu \mathrm{m})$ & $n$ \\
\hline Primary growth & Include oogonia and perinuclear oocytes. & $<150$ & 150 \\
\hline Cortical alveolar & $\begin{array}{l}\text { A distinct cortical alveolar stage is rare in petrale sole: cortical } \\
\text { alveoli mostly appear concurrently with vitellogenin. }\end{array}$ & $140-180$ & 7 \\
\hline $\begin{array}{l}\text { Primary } \\
\quad \text { vitellogenic (Vtg1) }\end{array}$ & $\begin{array}{l}\text { Initial accumulation of small yolk granules occurs peripherally and } \\
\text { mostly concurrently with cortical alveoli. Little to no oil droplet } \\
\text { accumulation. }\end{array}$ & $140-325$ & 81 \\
\hline $\begin{array}{l}\text { Secondary } \\
\quad \text { vitellogenic }(V \operatorname{tg} 2)\end{array}$ & $\begin{array}{l}\text { Small yolk granules completely fill cellular space. Little to no oil } \\
\text { droplet accumulation. }\end{array}$ & $250-650$ & 234 \\
\hline $\begin{array}{l}\text { Tertiary } \\
\quad \text { vitellogenic (Vtg3) }\end{array}$ & $\begin{array}{l}\text { Oil droplets begin to appear and increase in size and numbers } \\
\text { throughout this stage. }\end{array}$ & $450-775$ & 121 \\
\hline $\begin{array}{l}\text { Germinal vesicle } \\
\text { migration }\end{array}$ & $\begin{array}{l}\text { Migration of the nucleus occurs concurrently with initial yolk } \\
\text { coalescence (larger yolk granules). }\end{array}$ & $625-775$ & 27 \\
\hline $\begin{array}{l}\text { Germinal vesicle } \\
\text { breakdown }\end{array}$ & $\begin{array}{l}\text { The nuclear membrane breaks down as yolk continues to coalesce, } \\
\text { forming pale-pink "plates" within the oocyte. Oil begins to coalesce } \\
\text { into a single droplet. }\end{array}$ & $625-850$ & 12 \\
\hline Hydrated & Yolk and lipids are completely coalesced. & $>1200$ & 20 \\
\hline
\end{tabular}

with length and weight and is best described as a power function:

$$
\begin{aligned}
& P A F=a L^{\mathrm{b}} \text { or } \\
& P A F=a W^{\mathrm{b}},
\end{aligned}
$$

where $L$ is the total length (in millimeters) and $W$ is the somatic weight (in grams). The parameters $a$ and $b$ for each equation are the intercept and slope, respectively, of the linear natural-log-transformed least-squares regression fit to the data:

$$
\begin{aligned}
& \log (P A F)=\log (a)+(b \times \log (L)) \text { or } \\
& \log (P A F)=\log (a)+(b \times \log (W)) .
\end{aligned}
$$

The value for $a$ was reported after back-transformation by using the bias correction term $\exp \left(\sigma^{2} / 2\right)$. Values for $P$ and the coefficient of determination $\left(r^{2}\right)$ were reported for the log-transformed equation. Relative PAF $\left(P A F_{\text {rel }}\right)$ was described as a linear function of female $L$ or $W$ :

$$
\begin{aligned}
& P A F_{\text {rel }}=\mathrm{c}+(\mathrm{d} \times L) \text { or } \\
& P A F_{\text {rel }}=\mathrm{c}+(\mathrm{d} \times W),
\end{aligned}
$$

where $c$ and $d$ are the intercept and slope, respectively, of the least-squares regression fit to the data. To understand potential geographic effects, we compared the performance of models relating fecundity (PAF or relative PAF) to maternal size in the following ways: 1 ) without considering region (California or Pacific Northwest) as a covariate, 2) allowing for region-specific intercepts along with a shared effect of size (i.e., classic analysis of covariance), or 3) allowing for region-specific effects of size (i.e., modeling an interaction between region and maternal size). We used the difference between Akaike information criterion (AIC) values for 2 nested models ( $\triangle \mathrm{AIC}$ ) to select the most parsimonious models for each combination of size and fecundity predictors. Although in all cases the use of $\Delta \mathrm{AIC}$ resulted in selection of the model with an interaction between region and size as the best description of the data, we also present results for the size-only model because the use of this model could be more appropriate for stock assessments that do not distinguish among regions.

All statistical analyses were conducted by using $\mathrm{R}$ (vers. 3.4.3; R Core Team, 2017) with a significance level of 0.05 .

\section{Results}

Female petrale sole collected off California ranged in size from 305 to $600 \mathrm{~mm}$ TL (mean: $472 \mathrm{~mm}$ TL [standard deviation (SD) 48]) and in age from 4 to 20 years (mean: 9.4 years [SD 3.3]) (Table 1). Fish collected off Washington and Oregon measured 280-520 mm TL (mean: $436 \mathrm{~mm}$ TL [SD 63]) and had ages from 3 to 15 years (mean: 7.7 years [SD 2.8]) (Table 1). All macroscopic stages of ovarian development were observed in fish collected from California (Fig. 3); the only immature fish were collected in NWFSC bottom-trawl surveys. At the earliest collections, the majority of females had stage-2 ovaries. Spawning was first evident in September, and peak spawning occurred in December, as determined by the percentage of females with stage-3 ovaries. By January, the majority of females had completed spawning and had stage- 4 ovaries. The reproductive season appeared to start later in Pacific Northwest collections, with the majority of ovaries found at stage 2 in December and the first stage-3 ovaries collected in January. 

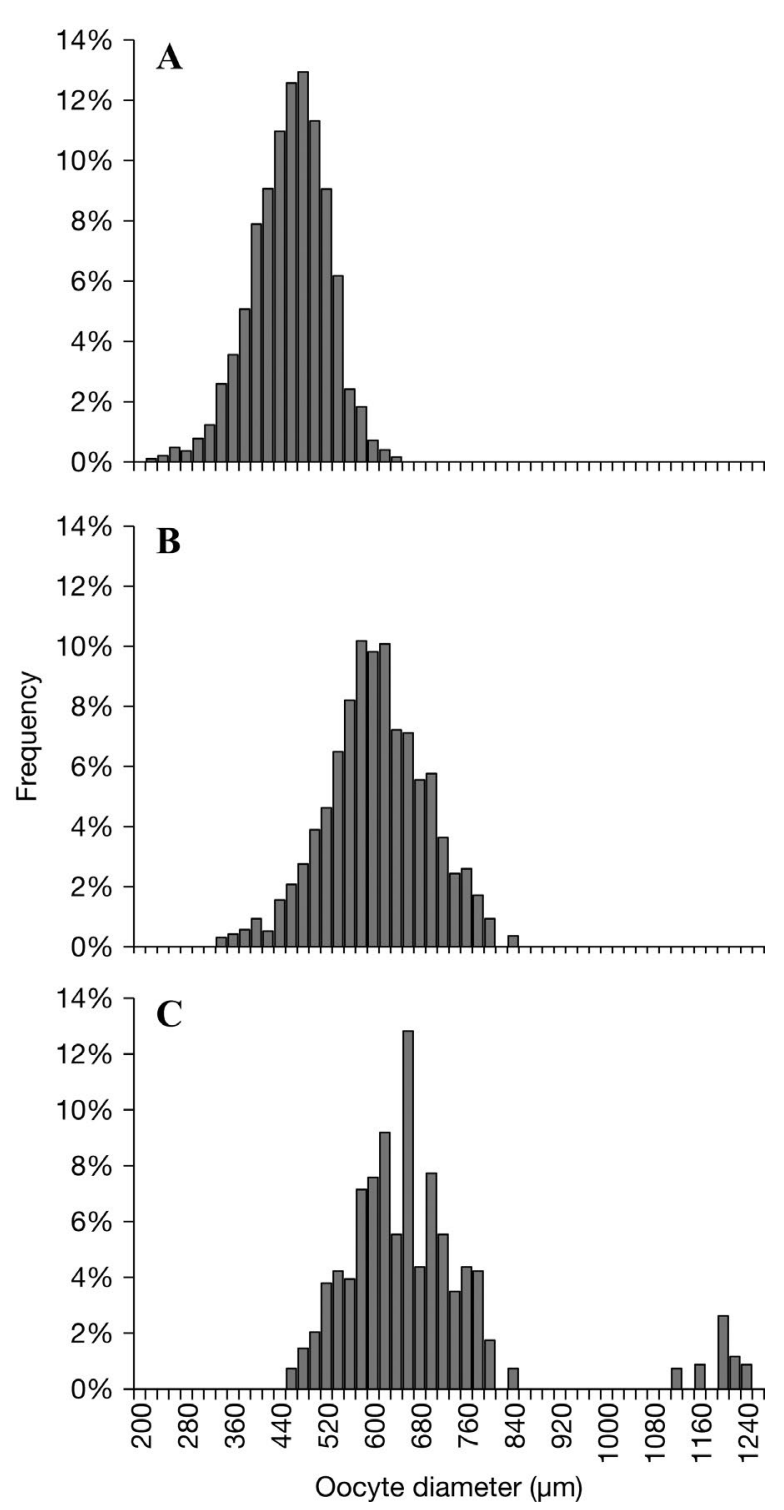

Figure 2

Representative examples of oocyte size-frequency distribution diagrams for ovarian samples taken from petrale sole (Eposetta jordani) collected off California, Oregon, and Washington in 2014-2017. Primary growth oocytes, which were $<150 \mathrm{um}$, are not included, and all oocytes are at the primary vitellogenic oocyte stage or further advanced. (A) An example of when recruitment of oocytes for the year was nearing completion, from a macroscopic-stage-2 ovary sampled in August. (B) An example of oocytes fully recruited before spawning has commenced, from a macroscopic-stage-2 ovary sampled in October. (C) An example of a female that had initiated spawning, from a macroscopic-stage-3 ovary sampled in October. The gap between primary and secondary growth oocytes evident in panels $\mathrm{B}$ and $\mathrm{C}$ indicates a determinate fecundity pattern for petrale sole.
Histological examination of ovarian tissues confirmed macroscopic assignment of developmental stages (Fig. 4) and provided evidence of the fecundity pattern and spawning strategy of petrale sole. Increasing size of perinucleolar stage oocytes signaled the earliest development. Interestingly, there appeared to be no distinct cortical alveolar oocyte stage, with cortical alveoli appearing concomitantly with vitellogenin (yolk protein). Oocytes developed somewhat asynchronously until a mid-vitellogenic state (Vtg2) because, presumably, recruitment from primary growth reserves was ongoing. Oocytes then developed synchronously to the tertiary vitellogenic stage (Vtg3), after which individual clutches underwent final maturation sequentially (observed histologically as ovaries with primary growth and Vtg3 oocytes with groups of oocytes at various stages of final maturation [e.g., germinal vesicle migration, germinal vesicle membrane breakdown, or hydration]). Once the leading cohort reached the Vtg3 stage, earlier vitellogenic stages were not observed (indicating recruitment from the primary growth stage was complete). This oogenesis pattern indicates that petrale sole exhibited a determinate fecundity pattern. The fecundity pattern was corroborated with examination of diagrams of oocyte size-frequency distribution that show a distinct gap between primary and secondary growth oocytes (Fig. 2).

The presence of POFs (from prior spawning events) with hydrating oocytes (destined for imminent spawning) and late vitellogenic oocytes (for future spawning activity) demonstrated that petrale sole exhibited batch spawning behavior (Fig. 4D) (Murua and Saborido-Rey, 2003). The exact number of spawning events could not be determined because the duration of POFs were unknown in this species; however, 2 or 3 distinct stages of POFs were found in many histological sections from ovaries with both vitellogenic and hydrating oocytes, indicating that at least 4 or 5 spawning events for an individual were common and that more were possible. Atresia of secondary growth oocytes appeared to be rare during the reproductive season, indicating minimal fecundity down regulation. A small percentage (14\%, or 1 of 7 ) of ovaries in the regressing phase appeared to be resorbing the final batch of oocytes at the end of the season.

Fecundity models including the interaction term of length or weight and region were the best fit on the basis of AIC (Table 4). Total PAF of the fish examined in this study ranged from 458,000 to over 3 million eggs and was significantly related to maternal size (Table 5, Fig. 5). Relative PAF values ranged from 481 to 1639 eggs per gram of somatic weight and was significantly related to maternal size in the combined and Pacific Northwest regional models (Table 5, Fig. 5); however, the slope parameter in the California regional model was not significantly different from zero (Table 4). The difference in the regional slopes for relative PAF means that a 56-cm-TL fish produced 1.25 times as many eggs per gram as a $40-\mathrm{cm}-\mathrm{TL}$ fish in California but produced 2.37 times as many eggs per gram as a 40-cm-TL fish off Washington and Oregon. This regional difference in the fecundity relationship appears to be driven by lower relative PAF for smaller 


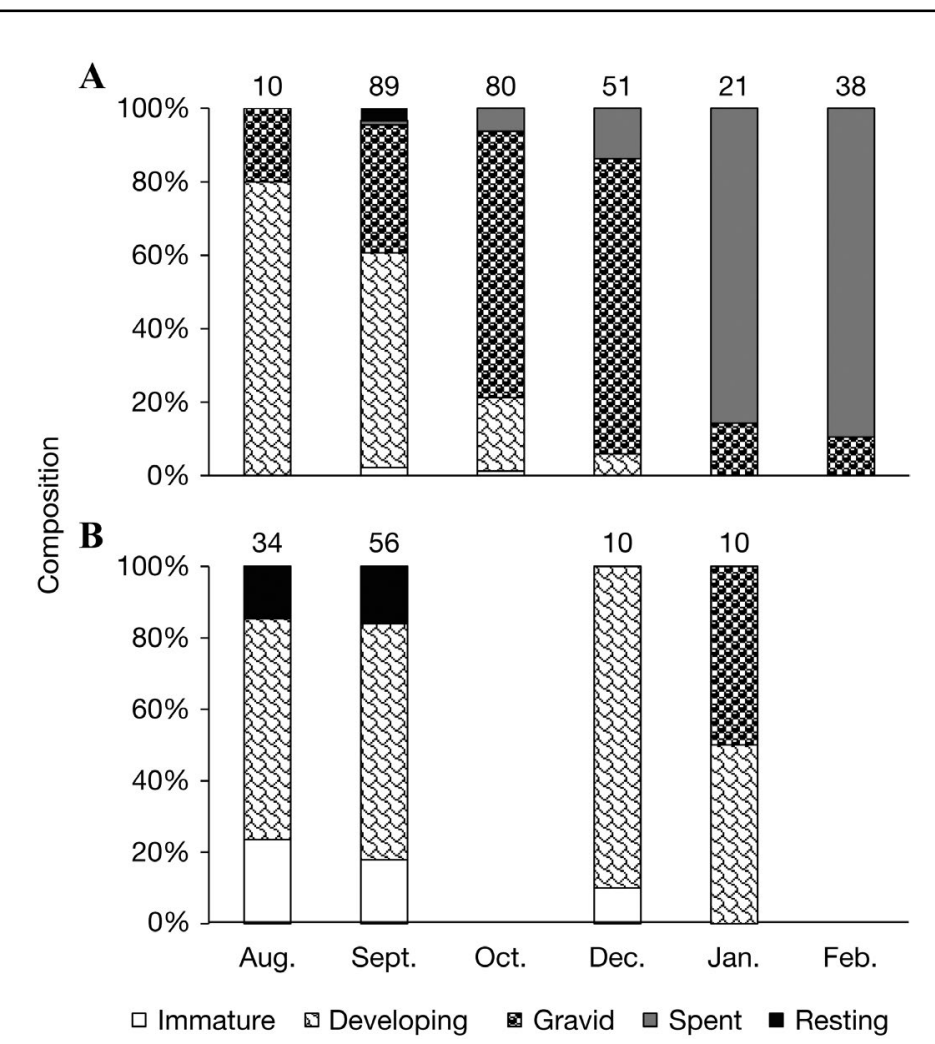

Figure 3

Composition of the macroscopic stages of ovarian development, by month, in petrale sole (Eopsetta jordani) collected off (A) California and (B) the Pacific Northwest (Oregon and Washington) in 20142017. The numerals above bars indicate number of samples.

fish in the data from the Pacific Northwest region relative to those from California. When all data are pooled, a 56-cm-TL fish produces 1.60 times as many eggs per gram as a 40-cm-TL fish.

\section{Discussion}

Accurate reproductive data are necessary for stock assessments. Even when the biology of a species is well understood, parameters such as fecundity exhibit spatiotemporal variation as a response to environmental conditions and body condition (McElroy et al., 2013; Beyer et al., 2015), and population shifts in egg production may occur over time as the demographics of a stock change (for example, when the number of small females increases) (Rideout and Morgan, 2007). Therefore, it is important to periodically revisit and review these types of data.

Maximum estimates of PAF ( $>3$ million eggs) for petrale sole along the West Coast of the United States were found to be more than double previous estimates (1.45 million eggs; Porter, 1964). Through histological examination of ovarian tissue and analysis of oocyte size-frequency distributions, it was determined that petrale sole employed a determinate batch spawning strategy, as opposed to the determinate total spawning strategy suggested by Porter (1964). This updated understanding of the petrale sole's reproductive biology renders Porter's fecundity estimates obsolete because those data likely include samples from females that had already initiated spawning for the season. Porter (1964) observed hydrated oocytes ("ripe eggs") scattered throughout ovaries but assumed the fish spawned all eggs in a single event annually in part because of the homogeneity in size of the remaining oocytes. The homogeneity that Porter (1964) observed is explained by our observation of all oocytes contributing to PAF developing to the late stages of vitellogenesis prior to the first spawning event (evidenced histologically by all secondary growth oocytes being in late stages of vitellogenesis without evidence of spawning activity [no POFs present]), with individual batches advancing sequentially (evidenced histologically by the presence of POFs, hydrating oocytes, and late-stage vitellogenic oocytes). Furthermore, Porter (1964) noted that, although most oocytes appeared to develop synchronously, there were some samples in which multiple sizes of oocytes were visible. He assumed that they would be resorbed and, therefore, did not include them in his fecundity estimates. However, on the basis of our observations, it is possible that oocyte recruitment was ongoing in those cases and, therefore, PAF would have been underestimated from those individuals. Interestingly, Porter (1964) did also observe regional differences in fecundity: fish from Eureka (Northern California) had a slightly greater number of eggs at length than those from Oregon, a finding consistent with what we observed in differences in relative PAF between small fish from Morro Bay (Central California) and those from Oregon and Washington.

Histological analysis in which hematoxylin and Eosin Y staining was used also demonstrated the lack of a distinct cortical alveolar stage oocyte in petrale sole. Primary growth (perinuclear stage) oocytes move into secondary growth with the appearance of cortical alveoli, a change that is triggered by the hormone gonadotropin (Wallace and Selman, 1981). In most fish, this oocyte stage is a distinct one that occurs prior to the appearance of vitellogenin; however, in petrale sole in our study, cortical alveoli appeared at the same time as the vitellogenin. Although rarely documented, the lack of a cortical alveolar stage has been observed in pollock (Pollachius virens) (Skjæraasen et al., 2016). This observation has little relevance in the context of our study; however, it is important to note that, although many aspects of oogenesis and reproductive biology can be generalized across teleosts, a great variety of reproductive patterns exist.

Previous reproductive studies of petrale sole were focused on fish collected primarily off Oregon and to a lesser extent Washington (Harry, 1959; Porter, 1964; 

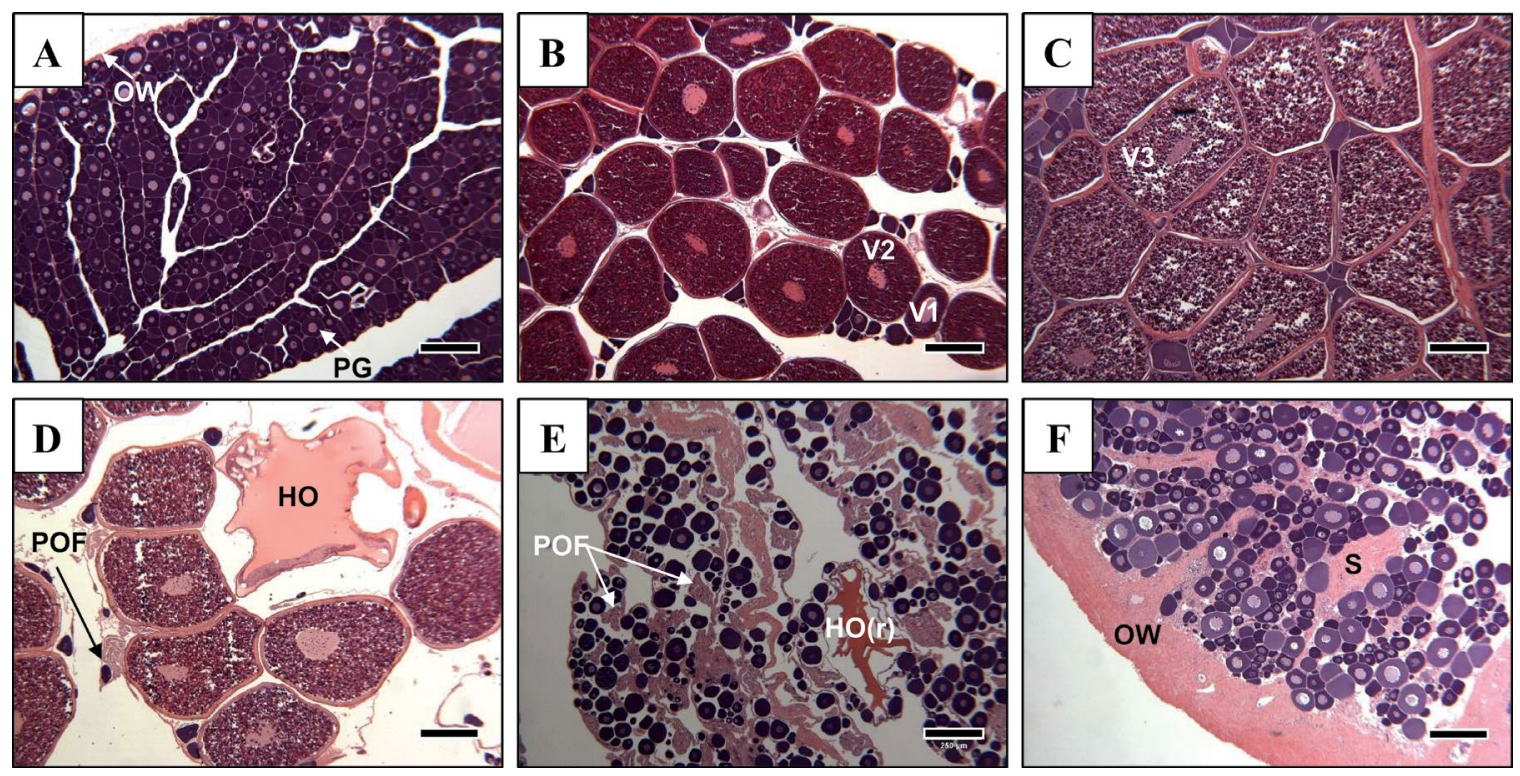

Figure 4

Photomicrographs from histological slides of ovarian tissue from petrale sole (Eopsetta jordani) collected in 20142017 off California, Oregon, and Washington, showing all phases of development: (A) immature, characterized by thin ovarian wall (OW), no stroma, and primary growth oocytes (PGs); (B) developing, characterized by oocytes at the mid-vitellogenic stage without evidence of spawning; (C) spawning capable, characterized by late vitellogenic oocytes without evidence of spawning; (D) actively spawning, characterized by hydrated oocytes (HOs) and postovulatory follicles (POFs); (E) regressing, characterized by POFs and only PGs; and (F) regenerating, characterized by a thick OW, only PGs, and thick stroma (S). V1=primary vitellogenic oocytes; V2=secondary vitellogenic oocyte; V3=tertiary vitellogenic oocyte; and $\mathrm{HO}(\mathrm{r})=$ residual $\mathrm{HO}$. The bars indicate a scale of $250 \mu \mathrm{m}$.

Hannah et al., 2002). The reproductive season of petrale sole observed off California in this study, with a peak in December, overlapped with that observed previously for petrale sole in Oregon by Harry (1959), with a peak in December-January, and for those in Oregon and Washington by Porter (1964), with spawning occurring sometime between December and March; however, the season ended earlier in California, with most spawning activity concluding by January. With our limited collections from the waters of the Pacific Northwest, the onset of spawning appears to occur later in more northerly waters, with data from other sources indicating a 1-month lag compared with the timing of spawning observed for petrale sole in California $\left(\right.$ Haltuch $^{2}$ ). Seasonal differences in the onset and intensity of upwelling are well known between California waters and those of the Pacific Northwest (e.g., Parrish et al., 1981), and such differences have been linked to shifts in the timing and the duration of spawning for other species of flatfish, such as the English sole (Parophrys vetulus) (Kruse and Tyler, 1983). Latitudinal variation in biological traits, such as growth and maturity, are common in many other commercially important fish species

\footnotetext{
${ }^{2}$ Haltuch, M. 2018. Personal commun. Northwest Fish. Sci. Cent., Natl. Mar. Fish. Serv., NOAA, 2725 Montlake Blvd. East, Bldg. South, Seattle, WA 98112-2097.
}

(Sampson and Al-Jufaily, 1999; McBride et al., 2013), and both temporal and spatial differences in growth for many species of groundfish on the West Coast of the United States, including the petrale sole, have been previously characterized (Stawitz et al., 2015; Gertseva et al., 2017).

In addition to providing more accurate estimates of PAF, maternal size was shown to significantly affect estimates of relative PAF in petrale sole, such that larger females contributed disproportionately more in terms of egg production compared with smaller females, as is common across fish taxa (e.g., Hixon et al., 2014; Barneche et al., 2018). Furthermore, regional variation in fecundity relationships were observed in this study. In California, the slope of the maternal size-fecundity relationship was less steep (and not statistically different from zero), compared with fish from the Pacific Northwest (Table 4, Fig. 5). This finding may be a reflection of differences in spawning season, such that fish off California have a longer spawning season and, therefore, can extend their reproductive efforts over a wider temporal range. However, the entirety of the spawning season was not studied sufficiently in the Pacific Northwest to verify that durations of the spawning seasons differ regionally. The observed differences in the slopes of the fecundity relationships appear to be driven by the data from small females, with larger females having similar fecundity estimates in both regions. Although 


\section{Table 4}

Selection criteria and parameters of the models for potential annual fecundity (PAF) and relative potential annual fecundity $\left(\mathrm{PAF}_{\text {rel }}\right)$ at length and weight in petrale sole (Eopsetta jordani). The base models consider only size (total length [TL] in millimeters or somatic weight [SW] in grams). Colons represent interactions between variables, and an asterisk (*) indicates the regional model that best fits the data on the basis of Aikake information criterion (AIC). Also provided are coefficients of determination $\left(r^{2}\right), P$-values, and values for the difference between Akaike information criterion (AIC) values for 2 nested models ( $\triangle A I C)$.

\begin{tabular}{llcrr}
\hline Fecundity relationship & Model & $r_{2}$ & $P$-value & \multicolumn{1}{c}{$\Delta$ AIC } \\
\hline PAF (length) & TL & 0.78 & $<0.001$ & 23.92 \\
& TL + Region & 0.81 & $<0.001$ & 16.66 \\
PAF (weight) & TL + Region + TL:Region* & 0.85 & $<0.001$ & 0.00 \\
& SW & 0.75 & $<0.001$ & 32.93 \\
& SW + Region & 0.81 & $<0.001$ & 14.66 \\
PAF $_{\text {rel }}$ (length) & SW + Region + SW:Region* & 0.85 & $<0.001$ & 0.00 \\
& TL & 0.24 & $<0.001$ & 16.88 \\
PAF $_{\text {rel }}$ (weight) & TL + Region & 0.38 & $<0.001$ & 5.03 \\
& Tl + Region + TL:Region* & 0.44 & $<0.001$ & 0.00 \\
& SW & 0.13 & 0.001 & 23.68 \\
& SW + Region & 0.31 & $<0.001$ & 8.94 \\
& SW + Region + SW:Region* & 0.40 & $<0.001$ & 0.00 \\
& & & & \\
\hline
\end{tabular}

Table 5

Fecundity ranges and fecundity relationship model parameters for petrale sole (Eopsetta jordani) collected during 2014-2017 off California and the Pacific Northwest (Oregon and Washington). The potential annual fecundity parameter $a$ is reported after back calculating from the log of length or weight by using the bias correction term exp $\left(\sigma^{2} / 2\right)$. The $95 \%$ confidence intervals for all parameters $(a, b, c$, and $d)$ are listed in parentheses. An asterisk $\left(^{*}\right)$ denotes a result that was not significant. Lengths were measured as total lengths. $n=$ number of samples.

\begin{tabular}{|c|c|c|c|c|c|c|c|c|c|c|c|}
\hline \multirow[b]{3}{*}{ Region } & \multirow[b]{3}{*}{$n$} & \multicolumn{5}{|c|}{ Potential annual fecundity (no. of oocytes) } & \multicolumn{5}{|c|}{$\begin{array}{c}\text { Potential annual relative fecundity (no. oocytes per } \\
\text { gram somatic weight) }\end{array}$} \\
\hline & & \multirow[b]{2}{*}{ Range } & \multicolumn{2}{|c|}{ Length (mm) } & \multicolumn{2}{|c|}{ Weight (g) } & \multirow[b]{2}{*}{ Range } & \multicolumn{2}{|c|}{ Length (mm) } & \multicolumn{2}{|c|}{ Weight (g) } \\
\hline & & & $a$ & $b$ & $a$ & $b$ & & $c$ & $d$ & $c$ & $d$ \\
\hline Combined & 70 & $\begin{array}{l}458,442- \\
3,003,377\end{array}$ & $\begin{array}{l}9.03 \times 10^{-7} \\
\left(2.5 \times 10^{-8}\right. \\
\left.3.19 \times 10^{-5}\right)\end{array}$ & $\begin{array}{l}4.55 \\
(3.97 \\
5.13)\end{array}$ & $\begin{array}{l}58.63 \\
(14.55 \\
236.18)\end{array}$ & $\begin{array}{l}1.39 \\
(1.20 \\
1.58)\end{array}$ & $\begin{array}{l}481- \\
1639\end{array}$ & $\begin{array}{l}-373.56 \\
(-956.04 \\
212.92)\end{array}$ & $\begin{array}{l}2.85 \\
(1.65 \\
4.06)\end{array}$ & $\begin{array}{l}678.4 \\
(476.67 \\
880.13)\end{array}$ & $\begin{array}{l}0.22 \\
(0.09 \\
0.35)\end{array}$ \\
\hline California & 49 & $\begin{array}{l}839,318- \\
3,003,377\end{array}$ & $\begin{array}{l}2.86 \times 10^{-4} \\
\left(7.24 \times 10^{-6}\right. \\
\left.1.13 \times 10^{-2}\right)\end{array}$ & $\begin{array}{l}3.63 \\
(3.03, \\
4.22)\end{array}$ & $\begin{array}{l}487.71 \\
(122.50, \\
1925.87)\end{array}$ & $\begin{array}{l}1.11 \\
(0.92 \\
1.30)\end{array}$ & $\begin{array}{l}833- \\
1639\end{array}$ & $\begin{array}{l}343.1 \\
(-287.10, \\
974.48)\end{array}$ & $\begin{array}{l}1.49^{*} \\
\left(0.02^{*},\right. \\
\left.2.78^{*}\right)\end{array}$ & $\begin{array}{l}963.29 \\
(754.88, \\
11171.70)\end{array}$ & $\begin{array}{l}0.07 \\
(-0.06 \\
0.20)\end{array}$ \\
\hline $\begin{array}{l}\text { Pacific } \\
\text { Northwest }\end{array}$ & 21 & $\begin{array}{l}458,442- \\
2,558,064\end{array}$ & $\begin{array}{l}1.16 \times 10^{-10} \\
\left(4.51 \times 10^{-15}\right. \\
\left.3.00 \times 10^{-6}\right)\end{array}$ & $\begin{array}{l}5.99 \\
(4.35 \\
7.63)\end{array}$ & $\begin{array}{l}3.38 \\
(0.09 \\
526.84)\end{array}$ & $\begin{array}{l}1.76 \\
(1.26 \\
2.26)\end{array}$ & $\begin{array}{l}481- \\
1189\end{array}$ & $\begin{array}{l}-1296.78 \\
(-3048.06, \\
454.06)\end{array}$ & $\begin{array}{l}4.57 \\
(0.77 \\
8.19)\end{array}$ & $\begin{array}{l}201.11 \\
(-361.42, \\
763.67)\end{array}$ & $\begin{array}{l}0.45 \\
(0.09 \\
0.81)\end{array}$ \\
\hline
\end{tabular}

intriguing, these relationships are based on a limited number of samples, particularly in large fish from the Pacific Northwest, and should be refined further before conclusions on regional variation can be drawn. Still, the observation that egg production is not proportional to maternal size in the combined model indicates that spawning stock biomass may not be an appropriate predictor of total egg production. Until regional values are established, the combined fecundity relationships (Table 4) are likely to be more appropriate for estimating total egg production in stock assessments.

A thorough understanding of the reproductive biology of a species is vital to providing accurate data for stock assessment models. For as long as the petrale sole has been assessed, fecundity appears to have been underestimated because of an incomplete understanding of the reproductive strategy of this species. The stronger size-dependent relationship observed in our data indicates that previous 


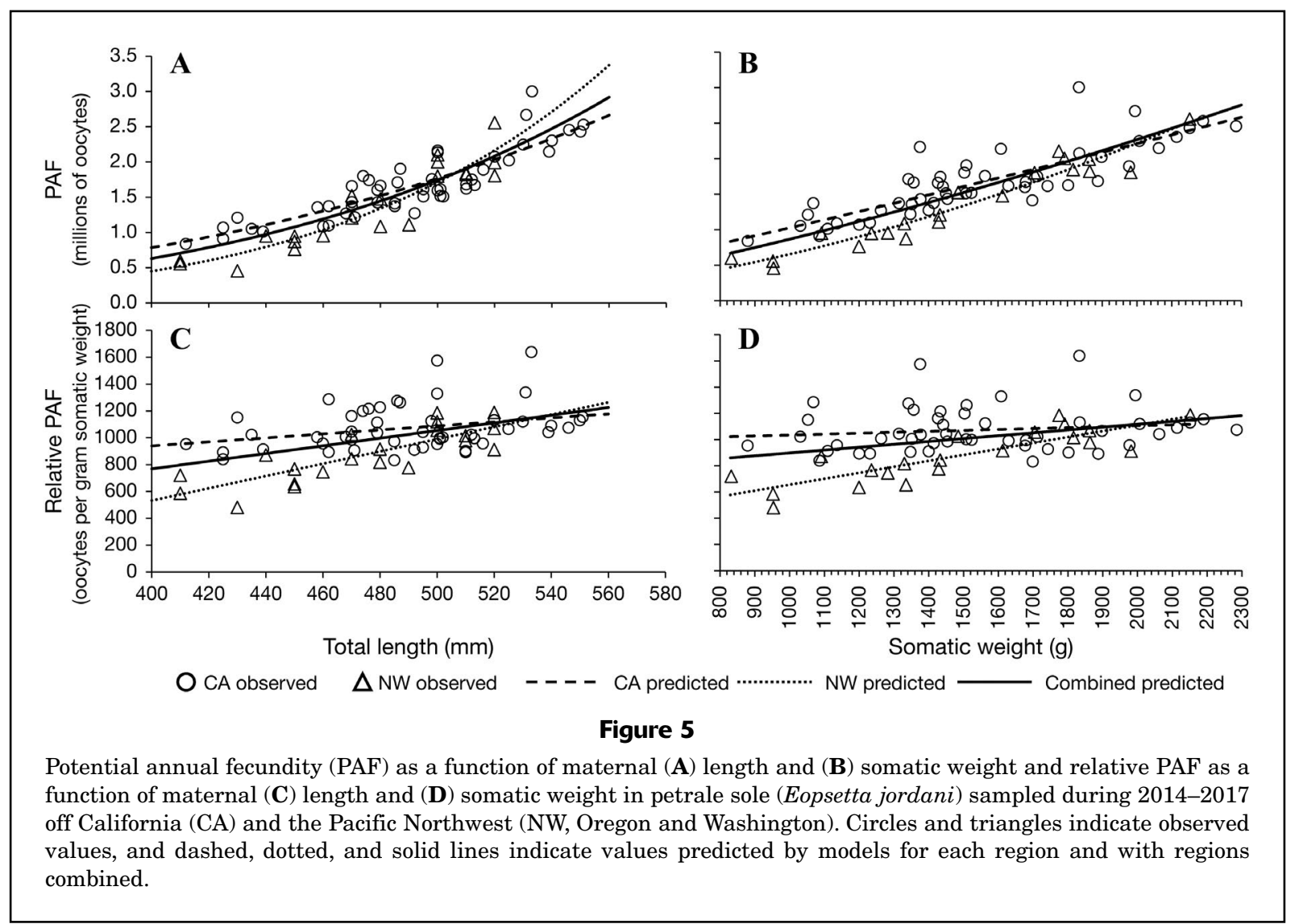

stock assessments of petrale sole conducted along the West Coast of the United States may have overestimated relative spawning output because they did not fully account for the increased relative egg production of larger individuals that would have been present in an unfished population. Moreover, the observation that female petrale sole produce not one, but several, batches of eggs throughout a given spawning season may have implications for how catch and effort data are evaluated from the winter fisheries (which take place on spawning grounds). However, given the uncertainties regarding potential differences in the relative fecundity relationship over space, additional research to better quantify reproductive output of this commercially important species would be ideal. Given the importance of this stock in commercial fisheries in both the United States and Canada, future studies into the reproductive ecology of petrale sole should include and pool data from a broader latitudinal range, including waters in California, the Pacific Northwest, and Canada, to better understand patterns of variability in fecundity and life history.

\section{Acknowledgments}

We are grateful to R. and T. Seitz (South Bay Wild, Astoria, OR), M. Gleason and S. Rienecke (The Nature Conservancy), and M. Head (NWFSC) for their cooperation in collecting commercial and survey samples; P. MacDonald
(NWFSC) for providing ages; E. Dick (SWFSC) for statistical assistance; and the processing crew and numerous interns for help developing the data. This manuscript was improved with comments from S. Beyer (SWFSC), M. Haltuch (NWFSC), and 3 anonymous reviewers. Funding was provided by the NMFS Cooperative Research Program.

\section{Literature cited}

Alverson, D. L., and B. M. Chatwin.

1957. Results from tagging experiments on a spawning stock of petrale sole, Eopsetta jordani (Lockington). J. Fish. Res. Board Can. 14:953-974. Crossref

Barneche, D. R., D. R. Robertson, C. R. White, and D. J. Marshall. 2018. Fish reproductive-energy output increases disproportionately with body size. Science 360:642-645. Crossref

Beyer, S. G., S. M. Sogard, C. J. Harvey, and J. C. Field.

2015. Variability in rockfish (Sebastes spp.) fecundity: species contrasts, maternal size effects, and spatial differences. Environ. Biol. Fish. 98:81-100. Crossref

Brown-Peterson, N. J., D. M. Wyanski, F. Saborido-Rey, B. J. Macewicz, and S. K. Lowerre-Barbieri.

2011. A standardized terminology for describing reproductive development in fishes. Mar. Coast. Fish. 3:52-70. Crossref

CDFW (California Department of Fish and Wildlife).

2013. Status of the fisheries report: an update through 2011, 224 p. Calif. Dep. Fish Wildl., Monterey, CA. [Available from website.] 
Gertseva, V., S. E. Matson, and J. Cope.

2017. Spatial growth variability in marine fish: example from Northeast Pacific groundfish. ICES J. Mar. Sci. 74:602-1613. Crossref

Haltuch, M. A., and A. Hicks.

2009. Status of the U.S. petrale sole resource in 2008, 148 p. Pac. Fish. Manage. Counc., Portland, OR. [Available from website.]

Haltuch, M. A., A. Hicks, and K. See.

2011. Status of the U.S. petrale sole resource in 2010, 175 p. Pac. Fish. Manage. Counc., Portland, OR. [Available from website.]

Haltuch, M. A., K. Ono, and J. Valero.

2013. Status of the U.S. petrale sole resource in 2012, 234 p. Pac. Fish. Manage. Counc., Portland, OR. [Available from website.]

Hannah, R. W., S. J. Parker, and E. L. Fruh.

2002. Length and age at maturity of female petrale sole (Eopsetta jordani) determined from samples collected prior to spawning aggregations. Fish. Bull. 100:711-719.

Harry, G. Y., Jr.

1959. Time of spawning, length at maturity, and fecundity of the English, petrale, and Dover soles (Parophrys vetulus, Eopsetta jordani, and Microstomus pacificus, respectively). Fish. Comm. Oregon., Res. Briefs 7(1):5-13.

Hixon, M. A., D. W. Johnson, and S. M. Sogard.

2014. BOFFFFs: on the importance of conserving old-growth age structure in fishery populations. ICES J. Mar. Sci. 71:2171-2185. Crossref

Humason, G. L.

1972. Animal tissue techniques, $3^{\text {rd }}$ ed., 468 p. W. H. Freeman, San Francisco, CA.

Keller, A. A., J. R. Wallace, B. H. Horness, O. S. Hamel, and

I. J. Stewart.

2012. Variations in eastern North Pacific demersal fish biomass based on the U.S. west coast groundfish bottom trawl survey (2003-2010). Fish. Bull. 110:205-222.

Ketchen, K. S., and F. C. R. Forrester.

1966. Population dynamics of the petrale sole, Eopsetta jordani, in waters off western Canada. Fish. Res. Board Can., Bull. 153, 204 p.

Kruse, G. H., and A. V. Tyler.

1983. Simulation of temperature and upwelling effects on the English sole (Parophrys vetulus) spawning season. Can. J. Fish. Aquat. Sci. 40:230-237. Crossref

Lowerre-Barbieri, S. K., K. Ganias, F. Saborido-Rey, H. Murua, and J. R. Hunter.

2011. Reproductive timing in marine fishes: variability, temporal scales, and methods. Mar. Coast. Fish. 3:71-91. Crossref

McBride, R. S., M. J. Wuenschel, P. Nitscheke, G. Thorton, and

J. R. King.

2013. Latitudinal and stock-specific variation in size- and age-at-maturity of female winter flounder, Pseudopleuronectes americanus, as determined with gonad histology. J. Sea Res. 75:41-51. Crossref

McElroy, W. D., M. J. Wuenschel, Y. K. Press, E. K. Towle, and

R. S. McBride.

2013. Differences in female individual reproductive potential among three stocks of winter flounder, Pseudopleuronectes americanus. J. Sea Res. 75:52-61. Crossref

Murua, H., and F. Saborido-Rey.

2003. Female reproductive strategies of marine fish species of the North Atlantic. J. Northwest Atl. Fish. Sci. 3:23-31. Crossref
Parrish, R. H., C. S. Nelson, and A. Bakun.

1981. Transport mechanisms and reproductive success of fishes in the California Current. Biol. Oceanogr. 1:175-203.

Pedersen, M. G.

1975. Movement and growth of petrale sole (Eopsetta jordani) tagged off Washington and southwest Vancouver Island. J. Fish. Res. Board Can. 32:2169-2177. Crossref

Porter, P.

1964. Notes on fecundity, spawning, and early life history of petrale sole (Eopsetta jordani), with descriptions of flatfish larvae collected in the Pacific Ocean off Humboldt Bay, California. M.S. thesis, 98 p. Humboldt State Coll., Arcata, CA.

$\mathrm{R}$ Core Team.

2017. R: a language and environment for statistical computing. R Foundation for Statistical Computing, Vienna, Austria. [Available from website, accessed January 2018.]

Rideout, R. M., and M. J. Morgan.

2007. Major changes in fecundity and the effect on population egg production for three species of north-west Atlantic flatfishes. J. Fish Biol. 70:1759-1779. Crossref

Sampson, D. B., and S. M. Al-Jufaily.

1999. Geographic variation in the maturity and growth schedules of English sole along the U.S. west coast. J. Fish Biol. 54:1-17. Crossref

Sampson, D. B., and Y. W. Lee.

1999. An assessment of the stocks of petrale sole off Washington, Oregon, and Northern California in 1998, 99 p. Pac. Fish. Manage. Counc., Portland, OR. [Available from website.]

Schneider, C. A., W. S. Rasband, and K.W. Eliceiri.

2012. NIH Image to ImageJ: 25 years of image analysis. Nat. Methods 9:671-675. Crossref

Skjæraasen, J. E., J. A. Devine, J. A. Godiksen, M. Fonn, H. OtterÅ, O. S. Kjesbu, B. Norberg, Ø. Langangen, and Ø. Karlsen. 2016. Timecourse of oocyte development in saithe Pollachius virens. J. Fish Biol. 90:109-128. Crossref

Starr, P. J., and J. Fargo.

2004. Petrale sole stock assessment for 2003 and recommendations for management in 2004. Can. Sci. Advis. Secr., Res. Doc. 2004/036, 80 p. [Available from website.]

Stawitz, C. C., T. E. Essington, T. A. Branch, M. A. Haltuch, A. B. Hollowed, and P. D. Spencer.

2015. A state-space approach for detecting growth variation and application to North Pacific groundfish. Can. J. Fish Aquat. Sci. 72:1316-1328. Crossref

Stawitz, C. C., F. Hurtado-Ferro, P. Kuriyama, J. T. Trochta, K. F. Johnson, M. A. Haltuch, and O. S. Hamel.

2016. Stock assessment update: status of the U.S. petrale sole resource in 2014, 210 p. Pac. Fish. Manage. Counc., Portland, OR. [Available from website.]

Turnock, J., M. Wilkins, M. Saelens, and C. Wood.

1993. Status of West Coast petrale sole in 1993. In Status of the Pacific coast groundfish fishery through 1993 and recommended biological catches for 1994: stock assessment and fishery evaluation, p. G1-G42. Pac. Fish. Manage. Counc., Portland, OR. [Available from website.]

Wallace, R. A., and K. Selman.

1981. Cellular and dynamic aspects of oocyte growth in teleosts. Am. Zool. 21:325-343. Crossref 